\title{
Genotoxicity Assessment of Birch-Bark Tar-A Most Versatile Prehistoric Adhesive
}

\author{
A. Baumgartner ${ }^{1,2}$, M. Sampol-Lopez ${ }^{1}$, E. Cemeli ${ }^{1}$, T. E. Schmid ${ }^{3}$, A. A. Evans ${ }^{4}$, \\ R. E. Donahue ${ }^{4}$, D. Anderson ${ }^{1}$ \\ ${ }^{1}$ Division of Biomedical Sciences, University of Bradford, Bradford, UK \\ ${ }^{2}$ Department of Pediatric Cardiology, University of Leipzig, Leipzig, Germany \\ ${ }^{3}$ Department of Radiotherapy and Radiooncology, Klinikum Rechts der Isar, \\ Technische Universität München, Munich, Germany \\ ${ }^{4}$ Division of Archaeological, Geographical and Environmental Sciences, University of Bradford, Bradford, UK \\ Email: d.anderson1@bradford.ca.uk
}

Received February 22 $2^{\text {nd }}, 2012$; revised March 30 $0^{\text {th }}, 2012$; accepted April $11^{\text {th }}, 2012$

\begin{abstract}
In the Mesolithic, birch-bark tar was commonly utilized across Europe and much of Asia as an adhesive to bind, seal and coat surfaces, but also quite frequently it was found to be chewed. The tar is known to contain biomarker triterpenoid compounds like betulin, crucial in preserving food and for medical applications. Aqueous, ethanolic and DMSO extracts were prepared from solid birch-bark tar and evaluated in vitro for the induction of DNA damage using Comet, micronucleus and sister-chromatid-exchange assays. Additionally, apoptosis induction was assessed. For the ethanolic extract, only the Comet assay showed a significant increase of DNA damage. All three extracts were able to significantly induce apoptosis. Thus, birch-bark tar seems capable of inducing genotoxic damage as well as apoptotic effects possibly originating from the triterpenoids' antimicrobial properties. We examine why prehistoric tar is found with tooth marks, the beneficial effects of birch-bark tar, and evidence for increased genotoxic risk upon exposure.
\end{abstract}

Keywords: Birch-Bark Tar; Genotoxicity; Micronuclei; Comet Assay; Apoptosis; Anthropology

\section{Introduction}

Birch-bark tar has long been known as an adhesive. Dating back to the Middle Palaeolithic period, pieces of birch-bark tar were found in a lignite open-mining pit near Königsaue, Germany, being made by Neanderthal hunter-gatherers around 48,000 years before present (BP) (radiocarbon dating) (Grünberg, 2002) and possibly as early as 80,000 BP (geo-stratigraphic dating) (Koller et al., 2001). By the start of the Mesolithic period around $9500 \mathrm{BP}$, birch-bark tar was extensively used across Europe from Norway to Greece (Stern et al., 2006) and this continued during the Neolithic period (Regert, 2004). So far, little is know about the actual manufacturing process in prehistoric times despite the wide-spread common use of this pyrolysed plant tar throughout Europe. The tar was not only employed for adhering, sealing, caulking and waterproofing (Charters et al., 1993) but also as an antifungal and antibacterial agent (Urem-Kotsou et al., 2002). Interestingly, birch-bark tar was also chewed (Aveling, 1997) - probably due to these precise antimicrobial properties (Aveling \& Heron, 1999). By assessing the light stable isotope $\delta^{13} \mathrm{C}$ content, prehistoric birchbark tar from Greece can easily be distinguished from that of northern Europe. So, even if we know little about the manufacturing process in early prehistoric times, it does seem evident that such adhesives were probably made and used locally rather than acquired through long-distance trading (Stern et al., 2006).

Five triterpenoid constituents from the lupane family: betulin

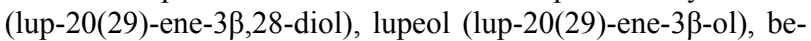
tulinic acid, lupenone and betulone are characteristic for the white birch bark, directly linking the tar chemically to the bo- tanical source (Figure 1). The pentacyclic triterpene alcohol, betulin, can be found in concentrations up to $30 \%$ of dry weight of birch bark (Betula pendula) (Alakurtti et al., 2006). On the other hand, other tar components, i.e. transformants of betulin, allobetulene (lupa-2,20(29)-diene-28-ol), and of lupeol, lupadiene (lupa-2-20(29)-diene), act as biomarkers of human action originating from pyrolytic dehydration during the manufacturing process (Dudd \& Evershed, 1999; Regert, 2004). When heating (pyrolysis) the bark of birch trees (e.g. European white

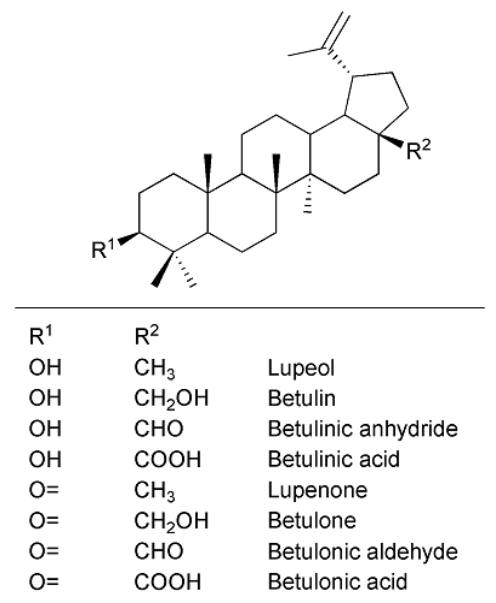

Figure 1.

Triterpenes of the outer birch bark of Betula pendula, B. papyrifera and B. neoalaskana. Modified according to (Krasutsky, 2006). 
birch Betula pendula Roth) under reducing conditions with limited air supply and a temperature of over $300^{\circ} \mathrm{C}$, the distillation product is an odorous dark-brown viscous pitch (Dudd \& Evershed, 1999).

Despite the mentioned beneficial qualities as a common tool for craftsmen, birch-bark tar originates from destructive heat distillation also generating an abundance of possible genotoxic substances, volatile and nonvolatile. As yet no toxicological studies have been undertaken to investigate the genotoxic potential of birch-bark tar. This present in-vitro study uses solvent extracts of water, ethanol and dimethyl sulfoxide (DMSO) from birch-bar tar to evaluate its genotoxic potential. Whole blood cultures as well as separated lymphocytes were treated in vitro with birch-bark tar extracts and analysed concentrating on classical cytogenetic endpoints such as induction of micronuclei (MN assay) and sister chromatid exchanges (SCE assay) as well as changes in DNA integrity (Comet assay). Additionally, flow cytometry (FCM) was applied to evaluate the tar's potential to induce cellular apoptosis or necrosis.

\section{Evidence for Use as a Medicinal Product}

There is ethnographic evidence for birch-bark tar and other products from birch trees in healing practices among traditional cultures located in the European and Asian boreal forests. The Yakut of Siberia, renowned for their desire for and care of horses, will use birch-bark tar to close wounds and use heated birch bark for bandaging (Sieroszewski et al., 1993: p. 361).

Birch-bark tar was made by the Fisher Lapps in Inari in the same way they recover tar from pine. They dug a hole on the side of a hill; the bark was rolled up to form a pipe and filled with more bark and resinous wood. The pipe was place in the hole on a slant with a pot or wooden container placed at the lower end. It was then covered with peat, sand and stone. Burning extended from a few hours to a whole day (Itkonen, 1984).

The Lapps appear to use a variety of remedies, including birch derived treatments, for toothaches. The person may chew birch-bark tar or pine pitch or simply rub the tooth with tar or pine pitch. When the ache is setting in, they will bite on a piece of birch wood until the pain disappears. Another interesting practice, suggestive that there is a medicinal property within the tree, occurs in winter when a chrysalis from a branch of birch is warmed up and the larvae taken out and pressed into the cavity in a tooth (Itkonen, 1984). Among the Inari-Lapps the elderly tend to have better teeth than younger Lapps and although their teeth may be much worn, they seem to have suffered very little from tooth disease. They suggest it is because they chew [birch] bark, which keeps their teeth in good condition (Itkonen, 1984).

Rheumatism is also treated with birch treatments by the Lapps. Tar water is made from pine pitch, birch-bark tar, or both and drunk. Young, resinous birch leaves will be layered on a bed or put in a sack and the patient, nude, will lie on them. Gout and rheumatism will also be treated by placing tinder on a piece of birch bark and blowing on it to start a small fire. The birch bark is held against the infected area and the fire blown on until it burns through the birch bark and burns into the skin, water and the rheumatism will flow from the burnt hole in the skin. The hole should be kept open as long as possible. The same process may also be used with a birch gnarl (Itkonen, 1984). For coughing, tar water is poured on a hot flagstone and the steam is breathed by the patient. Prior to bed, birch catkins or birch bark will be chewed by the patient. The saliva will be swallowed and the chew spat out. In some regions, bark from an old birch will be boiled and taken two or three times each day. Whooping cough is treated with a tea made from boiling birch catkins. Birch bark also is used in a variety of ways to treat diarrhea. Birch bark would be ground and mixed with meal and water and then baked. The resulting cake is eaten plain. Birch bark will also be boiled until the water turns red and has a very strong taste. It is mixed with sugar before being taken. Dry birch bark may also be chewed. The medicinal action of birch bark is attributed to tanning agents within the bark (Itkonen, 1984: p. 918). This is also the explanation for the value of willow bark, which is used in a large number of remedies, but, research has shown that it is the occurrence of salicylic acid in the bark.

\section{Material and Methods}

\section{Chemical Extracts and Treatment of Cells Template}

A sample of experimentally produced birch-bark tar was provided for analysis by the Hunter-Gatherer Laboratory of the Division of Archaeological, Geographical and Environmental Sciences, at the University of Bradford. Three different solvents, water, ethanol and DMSO, were used to prepare extracts with a concentration of $100 \mathrm{mg} / \mathrm{ml}$ each. The suspension was thoroughly mixed and kept for 7 days at $37^{\circ} \mathrm{C}$. After removal of the non-dissolvable precipitate, the extracts were then diluted to working stock concentrations of 10, 100 and $1000 \mu \mathrm{g} / \mathrm{ml}$. Human lymphocytes were treated in vitro with final concentrations of $0.1,1.0$ and $10 \mu \mathrm{g} / \mathrm{ml}$ in culture.

\section{Blood Samples, Culture and Treatment of Lymphocytes for the MN, SCE and FCM-Apoptosis Assays}

After informed consent, blood from healthy volunteers (donor A, male, age 33, and donor B, female, age 28) was obtained in heparinised vacutainers (Greiner) by venepuncture. Ethical approval was provided by the University of Bradford's Research Ethics Subcommittee involving human subjects (reference number $0405 / 8)$. Whole blood $(0.5 \mathrm{ml}$ each) was added to plastic culture flasks $\left(25 \mathrm{~cm}^{2}\right.$, Corning) containing RPMI 1640 medium with Glutamax (Gibco), 15\% foetal bovine serum (FBS, Sigma) and 1\% penicillin-streptomycin solution (Gibco), This basic culture medium was supplemented with $1 \%(\mathrm{v} / \mathrm{v})$ phytohaemagglutinin-M (PHA-M, Gibco) to initiate proliferation of T-lymphocytes in vitro. For the SCE assay, additional supplementation with $10 \mu \mathrm{M}$ of 5-bromo-2'-deoxy-uridine (BrdU; Sigma) for cell cycle control was needed. Cultures were incubated for 72 hours at $37^{\circ} \mathrm{C}$ in $5 \% \mathrm{CO}_{2}$ in air. For the $\mathrm{MN}$, SCE and FCM-apoptosis assays, the cultures were treated 24 hours after the start. The volume of treatment stock solutions added was kept constant to $1 \%$ of the total cell culture volume. For the $\mathrm{MN}$ assay, 44 hours after the start, cytochalasin B (Sigma) was added to produce a final concentration of $6 \mu \mathrm{g} / \mathrm{ml}$ in order to arrest cytokinesis for the rest of the incubation time. Cells were then harvested after the end of the 72 hours culture period. For the SCE assay, cells were arrested in metaphase 2 hours before the end of the culture by adding colcemid (Sigma) to a final concentration of $0.1 \mu \mathrm{g} / \mathrm{ml}$. The cultures for the FCM-based apoptosis assay received no supplementations. Cells treated with mitomycin C (Sigma) served as a positive control for the 
MN assay $(0.2 \mu \mathrm{M})$ and for the SCE and FCM-apoptosis assays $(0.1 \mu \mathrm{M})$.

\section{Lymphocyte Isolation for the Comet Assay}

Seven healthy individuals ( 4 males and 3 females) with an average age of $30.00 \pm 2.25$ years volunteered to donate blood. Lymphocytes were isolated using a Ficoll gradient (Lymphoprep, Axis-Shield) according to the manufacturer's instructions. Once a pellet with lymphocytes was obtained, it was resuspended in FBS and transferred into a cryovial containing DMSO (9 parts FBS, 1 part DMSO). This cell suspension was frozen at $-20^{\circ} \mathrm{C}$ overnight and then transferred to $-80^{\circ} \mathrm{C}$ for long-term storage.

\section{Cell Viability for Lymphocytes}

Cell viability was measured directly after treatment by Trypan blue exclusion (Krause et al., 1984; Pool-Zobel et al., 1992) and fluorescein diacetate/ethidium bromide (Hartmann \& Speit, 1997) (all chemicals from Sigma). The treatment concentrations selected for the present investigation resulted generally in viability rates over $90 \%$, but always higher than the required $75 \%$ (Henderson et al., 1998).

\section{Metaphase Preparation for SCE Assay and Differential Giemsa Staining}

After 72 hours, the cell suspensions were transferred to Falcon tubes and washed twice with phosphate-buffered saline (PBS, Sigma) at $37^{\circ} \mathrm{C}$. Each washing step was followed by a centrifugation (190 g for $10 \mathrm{~min}$ ) and removal of the supernatant. The subsequent hypotonic treatment was carried out with $75 \mathrm{mM} \mathrm{KCl}$ (Sigma) for $20 \mathrm{~min}$ at $37^{\circ} \mathrm{C}$. After centrifugation for $8 \mathrm{~min}$ and removal of the supernatant, the cells were fixed in Carnoy's solution (3 parts methanol/1 part glacial acetic acid, both from Sigma). The fixation step was repeated out three times. Chromosome preparations were obtained by pipetting $20 \mu 1$ of cell suspension onto clean glass slides. After airdrying, the preparations were aged for a minimum of one week at room temperature. Four slides per treatment (two cultures per treatment and each culture prepared in duplicate) were employed. For differential staining, fluorescence plus Giemsa (FPG) staining was applied (Perry \& Wolff, 1974). Briefly, slides with aged metaphase spreads were incubated in $1 \mu \mathrm{g} / \mathrm{ml}$ bisbenzimide (Sigma)/Weise buffer $\left(8 \mathrm{mM} \mathrm{Na}_{2} \mathrm{HPO}_{4}, 3.6 \mathrm{mM}\right.$ $\mathrm{KH}_{2} \mathrm{PO}_{4}, \mathrm{pH} 7.2$ ) solution for $20 \mathrm{~min}$ in the dark at room temperature, then rinsed and incubated in PBS for 90 min under a UV-A/B lamp. After a final $30 \mathrm{~min}$ incubation at $60^{\circ} \mathrm{C}$ in $2 \mathrm{x}$ SSC (Sigma), the slides were rinsed in pure water and chromatin was stained with $5 \%$ Giemsa (BDH) in Weise buffer during a 5 min incubation.

\section{Cytokinesis-Block MN Assay}

After 72 hours, the cultures were transferred into Falcon tubes, centrifuged (190 g for $8 \mathrm{~min}$ ) and the supernatant was removed. This was followed by a hypotonic treatment in 75 $\mathrm{mM} \mathrm{KCl}$ for $15 \mathrm{~min}$ at $4^{\circ} \mathrm{C}$ followed by another centrifugation. The cell pellets were then subjected to fixation with fresh Carnoy's solution. To each preparation three drops of formaldehyde $(38 \%, \mathrm{BDH})$ were added. The fixation was repeated twice without the addition of formaldehyde. Then, the cell suspension was dropped on clean glass slides $(20 \mu 1$ per drop, 2 drops per slide) and allowed to air-dry. Four slides per treatment (two cultures per treatment and each culture prepared in duplicate) were employed. Slides were stained with $5 \%$ Giemsa in phosphate buffer ( $\mathrm{pH} \mathrm{6.8)}$ for $10 \mathrm{~min}$, rinsed in pure water and airdried before being mounted with cover-slips. The scoring criteria were described in detail by Fenech and colleagues (Fenech et al., 2003; Fenech, 2007).

\section{Comet Assay}

DNA strand breaks were measured with the alkaline Comet assay using the method previously described (Anderson et al., 1997; Anderson et al., 1998) and reviewed (Tice et al., 2000). In brief, microscope slides were covered with a basic layer of $1 \%$ normal melting-point agarose in water (Invitrogen). The slides were dried overnight and then stored at room temperature. Cryovials with frozen lymphocytes were quickly thawed at $37^{\circ} \mathrm{C}$ and added to $1 \mathrm{ml}$ PBS containing $1 \%$ volume of the chemical treatment. After a treatment interval of $30 \mathrm{~min}$ at $37^{\circ} \mathrm{C}$ in Eppendorf $\mathrm{f}^{\mathbb{B}}$ tubes, followed by a centrifugation at $700 \mathrm{~g}$ (table-top centrifuge) for $5 \mathrm{~min}, 900 \mu \mathrm{l}$ of the supernatant were discarded and the pellet resuspended. The remaining lymphocyte suspension $(100 \mu \mathrm{l})$ was then mixed with $100 \mu \mathrm{l}$ of $1 \%$ low melting-point agarose in PBS (Invitrogen). Of this suspension, $100 \mu \mathrm{l}$ were pipetted on an agarose-coated slide. Slides were covered with cover slips and left on an ice-cold surface until the gel set. After removing the cover slip, a protective third layer of $0.5 \%$ low melting point agarose in PBS was added, spread using a cover slip and again allowed to set for approximately 5 min on an ice-cold surface. Then, the slides were immersed in lysis solution (2.5 M NaCl, $100 \mathrm{mM}$ EDTA, $10 \mathrm{mM}$ Tris, $1 \%$ Triton X-100 and $10 \%$ DMSO, pH set to 10 with $\mathrm{NaOH}$, all chemicals from Sigma). The slides were subjected to electrophoresis in a $\mathrm{pH}$ 13.5-electrophoresis buffer (1 mM EDTA and $300 \mathrm{mM} \mathrm{NaOH}$ ). The DNA was allowed to unwind within 30 min at $4^{\circ} \mathrm{C}$ in the electrophoresis buffer prior to electrophoresis being performed at $4^{\circ} \mathrm{C}$ for $30 \mathrm{~min}$ at a constant 25 volts $(0.75$ $\mathrm{V} / \mathrm{cm}$ ). The amperage was kept at $295-300 \mathrm{~mA}$ (adjusted by removing or adding electrophoresis buffer). Tris buffer $(0.4 \mathrm{M}$, $\mathrm{pH} 7.5$; Sigma) was used to neutralise the alkali buffer. Then, $50 \mu \mathrm{l}$ ethidium bromide $(20 \mu \mathrm{g} / \mathrm{ml}$; Sigma $)$ were added onto each slide, covered with cover slips and analysed within 3 hours. The slides were examined at $\times 400$ magnification on a fluorescence microscope (Leica, UK) equipped with a BP546/10 excitation filter and a $590 \mathrm{~nm}$ barrier filter. Fifty nuclei were scored and evaluated per concentration. Seven independent experiments were performed with isolated lymphocytes from 7 different subjects. A computerised image analysis system (Komet 4.0, Kinetic Imaging, Liverpool, UK) was used. In the Comet assay, Olive tail moment (OTM) was the parameter of choice since it was reported to provide good correlation with the dose of genotoxic agents used (Kumaravel \& Jha, 2006).

\section{Flow Cytometry (FCM) Apoptosis Assay}

After 72 hours of treatment, the tubes containing the treatment were centrifuged; the supernatant discarded and replaced by $40 \%$ RPMI 1640 with $40 \%$ FBS and $20 \%$ DMSO. In the first instance, the pellets were frozen overnight at $-20^{\circ} \mathrm{C}$ and then transferred to $-80^{\circ} \mathrm{C}$. The tubes were shipped in dry ice to the Department of Radiotherapy and Radiooncology in Munich. 
After storage at $-80^{\circ} \mathrm{C}$, the pellets were thawed and centrifuged for $10 \mathrm{~min}$ at $150 \mathrm{~g}$ at $8^{\circ} \mathrm{C}$. The supernatant was discarded and replaced by $5 \mathrm{ml}$ RPMI $1640+20 \%$ FBS and newly centrifuged in order to wash the pellet. The pellet was resuspended in the described medium, transferred to cell culture flasks and incubated overnight at $37^{\circ} \mathrm{C}$. Next day, the cultures were transferred into tubes, centrifuged at $150 \mathrm{~g}$, the supernatant discarded and resuspended in $5 \mathrm{ml}$ Annexin buffer (BD) and centrifuged again in the same conditions. The supernatant was discarded and the pellets were resuspended in $100 \mu$ l AnnexinV-FITC/Annexin buffer (1:100) and left in the dark for $15 \mathrm{~min}$.

The volume was increased up to $495 \mu \mathrm{l}$ with Annexin buffer. Immediately before the analysis, $5 \mu 1$ propidium iodide (Invitrogen) were added to achieve a 1:100 final dilution. Cells were analysed on a Becton Dickinson FACSCalibur flow cytometer using Cell Quest Software. Only single cells were gated for fluorescence analysis.

\section{Statistical Analysis}

For the Comet assay, after verifying normality (ShapiroWilks test) data were analysed by a one-way ANOVA with a Dunnett's post-hoc test using mean \pm SE of tail moments $(n=$ 7). For the MN assay, a one-tailed Fisher's exact test was applied to all parameters except the nuclear division index (NDI) where a $\chi^{2}$-test was applied. For the SCE assay, a t-test was applied for SCE and $\chi^{2}$-test for the proliferation rate index (PRI). Data from the FCM-apoptosis assay were statistically assessed with a $\chi^{2}$-test with Yate's correction. The statistical software used was Statistica 6.1 from StatSoft Inc. (Tulsa, OK, USA).

\section{Results}

In this study, three birch-bark tar extracts in water, ethanol and DMSO were evaluated in vitro for their genotoxic potential to induce DNA damage in lymphocytes from healthy individuals.

Using the alkaline Comet assay we investigated the DNA damage generated in vitro in lymphocytes based on seven experiments with lymphocytes from seven volunteers. The extent of the DNA damage on a single-cell level as seen in the Comet assay was described by the Olive tail moment (OTM) parameter. While the aqueous extract did not induce any DNA damage within the chosen dose range $(0.1,1$ and $10 \mu \mathrm{g} / \mathrm{ml})$, the ethanolic extract gave a clear dose response almost doubling the OTM when compared to the negative control with $p<0.001$ for all three doses (Figure 2). The DMSO extract on the other hand only induced slight DNA damage above the negative control, which was statistically significant at $0.1 \mu \mathrm{g} / \mathrm{ml}(p<0.05)$ and $10 \mu \mathrm{g} / \mathrm{ml}(p<0.01)$ but not at a dose of $1 \mu \mathrm{g} / \mathrm{ml}$.

The induction of genetic damage was also assessed by using the cytokinesis-block micronucleus (MN) assay. In Table 1, the results of the MN assay are listed. None of the extracts was able to increase the MN frequencies in vitro at a dose of $1 \mu \mathrm{g} / \mathrm{ml}$. However, there was a trend visible which showed that the DMSO extract almost doubled the MN frequency in lymphocytes from both healthy individuals (donors A and B), but this increase was not significant when compared to the negative control. The nuclear division index (NDI) however, yielded in a highly significant decrease $(1.77 ; p<0.001)$ for donor A when treating with the $1 \mu \mathrm{g} / \mathrm{ml}$ DMSO extract. Donor B on the other hand did not show a decline in NDI for the DMSO extract. Neither pure water nor DMSO showed any positive effect.

For the ethanolic extract, a significant decrease in NDI from 1.87 to $1.67(p<0.001)$ was seen only in lymphocytes from donor A, however, it seems $1 \%$ ethanol on its own entirely contributed to this decrease in the NDI. This was not observed for donor B. For the aqueous extract, a significant decrease in

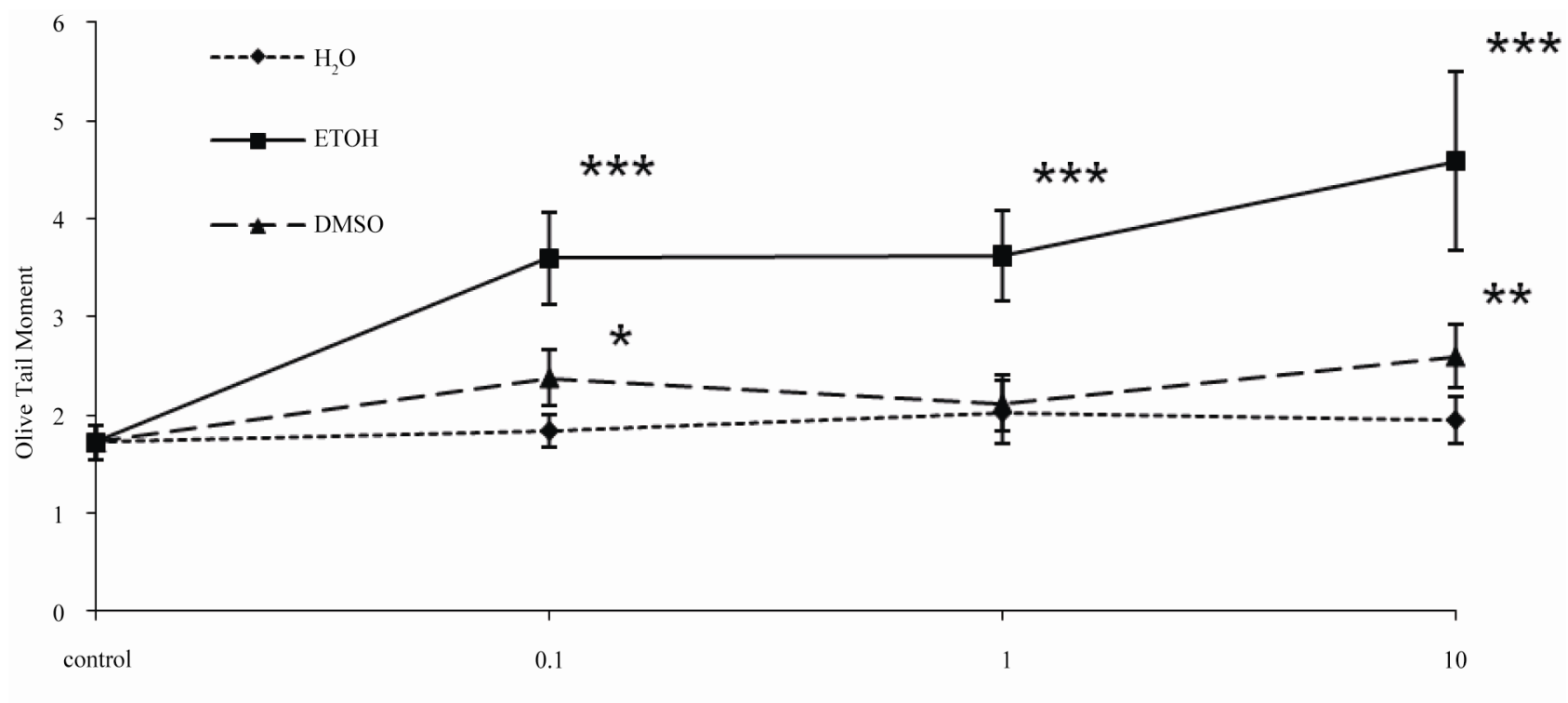

$\mu \mathrm{g} / \mathrm{ml}$

Figure 2.

Dose responses for aqueous $\left(\mathrm{H}_{2} \mathrm{O}\right)$, ethanolic $(\mathrm{ETOH})$ and DMSO extracts of prehistoric birch-bark tar using the alkaline Comet assay. Data were assessed for normality using the Shapiro-Wilks test. Data resulted in a normal distribution. Data were analysed by one-way ANOVA with a Dunnett's post-hoc test. For statistical interpretation, each concentration for each single extract was compared to the negative control $\left({ }^{*} p<0.05,{ }^{* *} p<0.01,{ }^{* * *} p\right.$ $<0.001)$. Data shown correspond to mean $\pm \mathrm{SE}$ of tail moments in seven individuals. 
Table 1.

Evaluation of aqueous, ethanolic and DMSO extracts of prehistoric birch-bark tar with the micronucleus (MN) assay.

\begin{tabular}{|c|c|c|c|c|c|c|c|c|c|}
\hline & Treatment concentration & NDI & $\% \mathbf{B i}$ & $\begin{array}{l}\Sigma \mathrm{MN} \text { per } \\
1000 \mathrm{Bi}\end{array}$ & $\begin{array}{c}\text { Bi containing } \\
\text { MN }\end{array}$ & $\begin{array}{c}\Sigma \text { NPB per } \\
1000 \mathrm{Bi}\end{array}$ & $\begin{array}{l}\Sigma \text { BiBuds per } \\
\qquad 1000 \mathrm{Bi}\end{array}$ & $\begin{array}{l}\Sigma \text { MN per } \\
1000 \text { Mono }\end{array}$ & $\begin{array}{c}\text { Mono containing } \\
\text { MN }\end{array}$ \\
\hline \multirow{8}{*}{ Donor A } & Negative control & 1.87 & 59.13 & 7.86 & 7.86 & 0.00 & 0.00 & 6.90 & 6.90 \\
\hline & $\mathrm{H}_{2} \mathrm{O} 1 \%$ & 1.85 & 62.75 & 5.87 & 5.87 & 0.00 & 0.00 & 3.91 & 3.91 \\
\hline & EtOH $1 \%$ & $1.68^{* * *}$ & 63.71 & 7.91 & 7.91 & 0.00 & 0.99 & 7.11 & 7.11 \\
\hline & DMSO $1 \%$ & $1.93^{*}$ & 70.01 & 3.91 & 3.91 & 0.00 & 0.00 & 1.30 & 1.30 \\
\hline & Birch-bark tar $\mathrm{H}_{2} \mathrm{O}$ extract, $1 \mu \mathrm{g} / \mathrm{ml}$ & 1.88 & 64.04 & 9.82 & 6.88 & 0.00 & 0.00 & 7.77 & 7.77 \\
\hline & Birch-bark tar EtOH extract, $1 \mu \mathrm{g} / \mathrm{ml}$ & $1.67^{* * *}$ & 64.03 & 5.99 & 5.99 & 0.98 & 0.00 & 0.00 & 0.00 \\
\hline & Birch-bark tar DMSO extract, $1 \mu \mathrm{g} / \mathrm{ml}$ & $1.77^{* * *}$ & 67.78 & 14.00 & 14.00 & 0.00 & 1.00 & 3.98 & 3.98 \\
\hline & MMC $0.2 \mu \mathrm{M}$ & $1.79^{*}$ & 58.78 & $29.67^{* * *}$ & $29.67^{* * *}$ & 0.00 & 0.00 & 3.77 & 3.77 \\
\hline \multirow{5}{*}{ Donor B } & Negative control & 1.54 & 44.89 & 9.94 & 9.94 & 0.00 & 0.00 & 3.89 & 3.89 \\
\hline & Birch-bark tar $\mathrm{H}_{2} \mathrm{O}$ extract, $1 \mu \mathrm{g} / \mathrm{ml}$ & $1.38^{* * *}$ & 30.22 & 13.56 & 13.56 & 0.00 & 0.00 & 3.94 & 3.94 \\
\hline & Birch-bark tar EtOH extract, $1 \mu \mathrm{g} / \mathrm{ml}$ & 1.52 & 42.76 & 8.12 & 8.12 & 0.00 & 0.00 & 2.85 & 2.85 \\
\hline & Birch-bark tar DMSO extract, $1 \mu \mathrm{g} / \mathrm{ml}$ & $1.76^{* * *}$ & 55.97 & 17.86 & 16.87 & 0.00 & 0.00 & 2.91 & 2.91 \\
\hline & $\mathrm{MMC} 0.2 \mu \mathrm{M}$ & $1.66^{* * *}$ & 51.78 & $30.00^{* *}$ & $30.00^{* *}$ & 0.00 & 1.00 & $9.28^{*}$ & 7.73 \\
\hline
\end{tabular}

Values for the parameters scored: NDI (nuclear division index), \% Bi (\% binucleated cells), $\Sigma \mathrm{MN}$ per $1000 \mathrm{Bi}$ (total number of MN per 1000 binucleated cells), Bi containing MN (number of binucleated cells containing MN out of 1000 binucleated), $\Sigma$ NPB per $1000 \mathrm{Bi}$ (total number of nucleoplasmic bridges per 1000 binucleated cells), $\Sigma$ BiBuds per $1000 \mathrm{Bi}$ (total number buds per 1000 binucleated cells), $\Sigma \mathrm{MN}$ per 1000 Mono (total number of MN per 1000 cells) and Mono containing MN (number of mononucleated cells containing MN out of 1000 cells). Statistical comparisons were carried out between the negative control and each of the treatments. One-tailed Fisher's exact test was applied to $\Sigma$ MN per $1000 \mathrm{Bi}$, Bi containing MN, $\Sigma$ NPB per $1000 \mathrm{Bi}, \Sigma \mathrm{BiBuds}$ per $1000 \mathrm{Bi}$, $\Sigma \mathrm{MN}$ per $1000 \mathrm{Mono}$ and Mono containing MN. $\chi^{2}$-test was applied to NDI $\left({ }^{*} p<0.05,{ }^{* *} p<0.01\right.$ and $\left.{ }^{* * *} p<0.001\right)$.

NDI was shown only donor B together with a non-significant increase in $\mathrm{MN}$. When focussing on other parameters like the frequency of $\mathrm{MN}$ in mononucleated cells, nuclear buds and nuclear plasmatic bridges (NPB), no significant increases or modulations were recorded.

The SCE assay is able to detect an increased exchange of DNA stretches between two sister chromatids of a duplicating chromosome after treatment. When using this assay, the aqueous and the ethanolic extract $(1 \mu \mathrm{g} / \mathrm{ml})$ exhibited statistically significant decreases in the frequency for SCEs per 50 cells (see Table 2), but only for donor A. For donor B, no effect was seen regarding SCEs.

This present investigation also evaluated the induction of apoptosis employing a flow cytometry based apoptosis assay (Vermes et al., 1995). Lymphocytes were treated in culture similarly as for the MN and SCE assays, however, without any addition of cell cycle inhibitors. Table 3 shows that the solvents $1 \%$ ethanol and $1 \%$ DMSO were capable of significantly inducing apoptosis (both slightly above 2.5 fold, $p<0.001$ ). For donor A, all the extracts showed a highly significant dose response $(p<0.001)$ with increasing apoptotic frequencies. The aqueous, ethanolic and DMSO extracts showed increases of 6.2-fold, 7-fold and 11.9-fold, respectively, when compared to the negative control. Even when comparing the ethanolic and the DMSO extracts to the solvent controls they still showed increases of 2.9-fold and 4.6-fold, respectively. For donor B, apoptosis was statistically significantly induced by the birchbark tar extracts, however, at much lower levels when compared to donor A.

\section{Discussion}

In 1991, the Tyrolean Iceman "Oetzi" was found in a slightly

\section{Table 2.}

Evaluation of aqueous, ethanolic and DMSO extracts of prehistoric birchbark tar with the sister-chromatid exchange (SCE) assay.

\begin{tabular}{|c|c|c|c|}
\hline & Treatment concentration & SCE/cell \pm S.E. & PRI \\
\hline \multirow{8}{*}{ Donor A } & Negative control & $7.12 \pm 0.44$ & 1.74 \\
\hline & $\mathrm{H}_{2} \mathrm{O} 1 \%$ & $6.00 \pm 0.28$ & $1.98^{* *}$ \\
\hline & EtOH $1 \%$ & $8.30 \pm 0.92$ & $1.89^{*}$ \\
\hline & DMSO 1\% & $7.54 \pm 0.68$ & 1.85 \\
\hline & Birch-bark tar $\mathrm{H}_{2} \mathrm{O}$ extract, $1 \mu \mathrm{g} / \mathrm{ml}$ & $4.02 \pm 0.26^{* * *}$ & 1.82 \\
\hline & Birch-bark tar EtOH extract, $1 \mu \mathrm{g} / \mathrm{ml}$ & $5.52 \pm 0.38^{* *}$ & $1.89^{*}$ \\
\hline & Birch-bark tar DMSO extract, $1 \mu \mathrm{g} / \mathrm{ml}$ & $6.90 \pm 0.38$ & $1.96^{* *}$ \\
\hline & MMC $0.1 \mu \mathrm{M}$ & $12.16 \pm 1.00^{* * *}$ & $1.98^{* *}$ \\
\hline \multirow{5}{*}{ Donor B } & Negative control & $7.82 \pm 0.54$ & 1.84 \\
\hline & Birch-bark tar $\mathrm{H}_{2} \mathrm{O}$ extract, $1 \mu \mathrm{g} / \mathrm{ml}$ & $7.06 \pm 0.56$ & 1.87 \\
\hline & Birch-bark tar EtOH extract, $1 \mu \mathrm{g} / \mathrm{ml}$ & $7.36 \pm 0.61$ & 1.81 \\
\hline & Birch-bark tar DMSO extract, $1 \mu \mathrm{g} / \mathrm{ml}$ & $7.78 \pm 0.69$ & 1.83 \\
\hline & $\mathrm{MMC} 0.1 \mu \mathrm{M}$ & $15.36 \pm 0.86^{* * *}$ & $1.65^{* *}$ \\
\hline
\end{tabular}

Values for the parameters scored: SCE/cell \pm S.E. (mean of sister-chromatid exchanges for 50 cells \pm standard error) and PRI (proliferative rate index). Statistical comparisons were carried out between the negative control and each of the treatments. The t-test was applied for SCE and $\chi^{2}$-test for PRI $\left({ }^{*} p<0.05,{ }^{* *} p<0.01\right.$ and $\left.{ }^{* * *} p<0.001\right)$.

retrieving glacier in the Alps having died approximately in the Late Neolithic around $5200 \mathrm{BP}$. The flint stones of his arrows as well as the copper blade of his hatchet were fixed onto wooden shafts with an organic agglutinant (Sauter et al., 2000). High levels of betulin and lupenol and lower levels of betulinic 
Table 3.

Evaluation of aqueous, ethanolic and DMSO extracts of prehistoric birchbark tar with the FCM-apoptosis assay.

\begin{tabular}{llc}
\hline Treatment/Concentration $(\boldsymbol{\mu g} / \mathbf{m l})$ & Apoptosis (\%) \\
\hline $\mathrm{H}_{2} \mathrm{O} 1 \%$ (Negative control) & 5.66 \\
EtOH 1\% & $14.29^{* * *}$ \\
& DMSO 1\% & $14.65^{* * *}$ \\
Donor A & Birch-bark tar $\mathrm{H}_{2} \mathrm{O}$ extract, $1 \mu \mathrm{g} / \mathrm{ml}$ & $35.01^{* * *}$ \\
& Birch-bark tar EtOH extract, $1 \mu \mathrm{g} / \mathrm{ml}$ & $42.06^{* * *}$ \\
& Birch-bark tar DMSO extract, $1 \mu \mathrm{g} / \mathrm{ml}$ & $67.24^{* * *}$ \\
& MMC 0.1 $\mu \mathrm{M}$ & $33.12^{* * *}$ \\
\hline H $2 \mathrm{O} 1 \%(\mathrm{Negative}$ control) & 3.95 \\
Birch-bark tar $\mathrm{H}_{2} \mathrm{O}$ extract, $1 \mu \mathrm{g} / \mathrm{ml}$ & $12.41^{* * *}$ \\
Birch-bark tar EtOH extract, $1 \mu \mathrm{g} / \mathrm{ml}$ & $17.68^{* * *}$ \\
Donor B & $14.92^{* * *}$ \\
& Birch-bark tar DMSO extract, $1 \mu \mathrm{g} / \mathrm{ml}$ & $31.55^{* * *}$ \\
\hline
\end{tabular}

The values for the apoptosis are presented as a percentage of the apoptotic events and the total gated. Two independent experiments were performed on 2 subjects. The $\chi^{2}$-test with Yate's correction was applied $\left({ }^{*} p<0.05,{ }^{* *} p<0.01\right.$ and ${ }^{* * *} p<$ $0.001)$. As a positive control mitomycin C (MMC) was used.

acid showed that this adhesive was birch-bark tar originating exclusively from the bark of Betula pendula birch trees (Hayek et al., 1989; Sauter et al., 2000). It was produced via destructive dry distillation of dried bark under anoxic conditions with temperatures around $340^{\circ} \mathrm{C}$ leaving betulin and lupenol as biomarkers almost unchanged. Higher temperatures in the production process $\left(>400^{\circ} \mathrm{C}\right)$ would have otherwise resulted in heat degradation markers like lupenone (lup-20(29)-ene-3-one) and lupadiene (lupa-2,20(29)-diene) (Regert \& Rolando, 1996; Koller et al., 2001), which were only found in small concentrations. In addition to the terpenoids high amounts of the lipid material suberin can be found in the tar (Modugno et al., 2006) preventing water from penetrating the material.

Betulin, lupenol and especially betulinic acid have recently been proven to exhibit anti-malarial, anti-HIV, anti-fungal and antibacterial properties, and to be selectively cytotoxic against a number of tumour types (Yogeeswari \& Sriram, 2005; Alakurtti et al., 2006; Dominguez-Carmona et al., 2010). This might have been the reason why our ancestors used birch-bark tar to preserve fermented beverages (Urem-Kotsou et al., 2002). It has been argued that the tar of the birch bark was also quite generally used as "chewing gum" in prehistoric northern Europe stretching back at least 9,000 years (Aveling, 1997; Aveling \& Heron, 1999). Potential explanations for this behaviour include the possible use as a narcotic, in rituals or for medical reasons due to the tar's antimicrobial properties. But the explanation for chewing the tar could be much simpler such as for removing milk teeth or just to pacify children as most chewers were 6 to 15 years old (Aveling, 1997; Aveling \& Heron, 1999). Ethnographic information presented earlier showed that not long ago birch-bark tar was used for various dental and gum problems, which would also explain the tooth or teeth impressions in tar recovered from prehistoric contexts. Whatever its use, it seems that in prehistoric times birch-bar tar was a commonly used product which came in prolonged contact with skin and the oral cavity. Inhalation of more volatile chemical components cannot be excluded when the tar was made and used in its viscous form after heating for various processes.

In this study we investigated the genotoxic potential of birch-bark tar. Knowing the fact that e.g. betulin and betulinic acid as pure chemicals are almost insoluble in aqueous media (Drag et al., 2009), three different extraction solvents generally used as solvents in toxicology were chosen due to their different hydrophilic properties: pure water, ethanol and DMSO. At the highest dose of $10 \mu \mathrm{g} / \mathrm{ml}$ the ethanolic extract of birch-bark tar generated an OTM of $4.59 \pm 0.91$ in the Comet assay, which shows a highly significant induction of DNA damage (Figure 2). The induced damage ranged almost at the same level as that of hydrogen peroxide, a genotoxin widely used as a positive control, which generated at $100 \mu \mathrm{M}$ OTM values of $5.59 \pm 0.36$ (data not shown in Figure 2). The DMSO extract induced only slight but significant DNA damage while the aqueous extract did not show any induction of damage. It has been shown that betulinic acid can generate reactive oxygen radicals (ROS) and also inhibit topoisomerase I, contributing to the DNA damage seen with the Comet assay (Eiznhamer \& Xu, 2004). Despite the fact that triterpenes are the most abundant group of compounds in birch-bark tar as seen with gas chromatography (Charters et al., 1993; Aveling \& Heron, 1999), other genotoxically active compounds even if lower concentrated might contribute to the overall genotoxic damage.

In our study, the micronucleus assay only showed a trend towards the induction of micronuclei (Table 1). The 2-fold increase compared to the control for the DMSO extract, however, was not found to be statistically significant. Only the nuclear division index was significantly decreased for the ethanolic and the DMSO extract. For the sister-chromatid exchange assay, no significant induction of SCEs was seen (Table 2). Lupenol and betulinic acid, compounds found in birch bark have been shown to be non-toxic for normal cells but highly potent chemopreventive and chemotheraputic agents alleviating inflammation and cancer (Saleem et al., 2009). This fact most likely supports the use of birch-bark tar as an antimicrobial in prehistoric times as no adverse effects were obvious. Due to the remarkable biological and medical aspects of birch-bark triterpenes, especially the abundant triterpenoids betulin, betulinic acid and lupenol these compounds are nowadays forming a new class of anti-cancer bioactive compounds (Krasutsky, 2006). Betulin by itself has proven to also bind to GABA receptors thus showing beneficial central nervous system effects in vivo in mice (Muceniece et al., 2008).

Early apoptosis is characterised by the translocation of phosphatidylserine (PS) from the inner to the outer side of the lipid bilayer of the plasma membrane, disturbing the normal asymmetrical distribution of PS. Once exposed to the extracellular environment, PS serves as a signal for phagocytosis (Schlegel $\&$ Williamson, 2001). The exposed PS can also act as an anchor for a $\mathrm{Ca}^{2+}$-dependent phospholipid binding protein, Annexin V. Conjugated to a fluorochrome, Annexin V-FITC can quantitatively and rapidly detect early apoptotic cells when used in a FCM-apoptosis assay (Vermes et al., 1995). To exclude necrotic cells the vital dye propidium iodide, which can only penetrate leaky plasma membranes and stain nuclear chromatin, is used. The results for such a flow cytometry apoptosis assay in our study showed for the aqueous, ethanolic and the DMSO extracts of birch-bark tar a significant induction of apoptotic cells - more pronounced for donor A showing a more distinct dose-response than for donor B (Table 3). It has been shown 
that betulinic acid can induce apoptosis in sensitive cells in a p53 and CD95 independent fashion functioning possibly through a mitochondrial-mediated pathway, however, it can also generate reactive oxygen species (ROS) and inhibit topoisomerase I (Eiznhamer \& Xu, 2004).

While the Comet assay detects genetic integrity changes mostly in the form of alkaline labile sites, single- and doublestrand breaks, the MN assay and the SCE assay primarily target cytogenetic changes in the cell. These changes have already escaped inherent repair mechanisms and have manifested themselves for instance as $\mathrm{MN}$, i.e. chromosomal fragments. When taking the results of the all three employed assays into account, it seems that the genotoxic impact of birch-bark tar caused DNA damage, but did not develop into permanent cytogenetic damage - maybe even due to induced apoptosis. However, this should not diminish the potential health risk of a genotoxin as deficiency in mismatch repair of DNA damage can result in increased mutations and lead to cancer (Abdel-Rahman, 2008).

The birch-bark tar used for this study has gone through a process of aging lasting at least a few years and may have lost the more volatile portions through evaporation while resinification has made the tar/pitch rather solid. Due to a loss of volatile substances the tar might have lost some of its genotoxic impact, but this study clearly shows that birch-bark tar has the potential to damage DNA of exposed cells and to induce apoptosis possibly due to the characteristic compounds found in the bark of birch trees. The antimicrobial and apoptosis-inducing aspects made the tar material a useful tool for specific preservative and/or medical procedures.

We shall never know for sure whether the individual use of birch-bark tar on skin or in the oral cavity had done more harm than good. Our results indicate that birch-bark tar used by our ancestors increased their genotoxic risk, but was also beneficial to them due to the innate birch-bark compounds. Our review of the ethnographic literature also indicates that it was, and may still be, used for medicinal purposes by some peoples and provides a much more logical explanation for the tooth marks observed in prehistoric birch-bark tar. Additional studies will be necessary to further characterise the potential genotoxicity and medicinal potential of birch-bark tar in greater detail.

\section{Acknowledgements}

The authors want to thank the former MSc students Ms Lin "Betty" Liu and Mr. Khaled Lamin for their help in the laboratory. A number of grants did support this collaborative study: Dr Randolph Donahue was awarded a grant of the University of Bradford "Research Matters" for Palaeopharmacology. Dr Adrian Evans' research has been funded by NERC, UK (grant NER/S/ A/2004/12213). Ms Magdalena Sampol-Lopez was supported by The DaVinci Scholarship provided by CAEB of the Balearic Islands, Spain.

\section{REFERENCES}

Abdel-Rahman, W. M. (2008). Genomic instability and carcinogenesis: An update. Current Genomics, 9, 535-541. doi: $10.2174 / 138920208786847926$

Alakurtti, S., Makela, T., Koskimies, S., \& Yli-Kauhaluoma, J. (2006). Pharmacological properties of the ubiquitous natural product betulin. European Journal of Pharmaceutical Sciences, 29, 1-13. doi:10.1016/j.ejps.2006.04.006

Anderson, D., Yu, T. W., Dobrzynska, M. M., Ribas, G., \& Marcos, R.
(1997). Effects in the comet assay of storage conditions on human blood. Teratogenesis, Carcinogenesis, and Mutagenesis, 17, 115-125. doi:10.1002/(SICI)1520-6866(1997)17:3<115::AID-TCM3>3.0.CO; $\underline{2-K}$

Anderson, D., Yu, T. W., \& McGregor, D. B. (1998). Comet assay responses as indicators of carcinogen exposure. Mutagenesis, 13, 539-555. doi:10.1093/mutage/13.6.539

Aveling, E. (1997). Chew, chew that ancient chewing gum. British Archaeology, 21, 1-2.

Aveling, E. M., \& Heron, C. (1999). Chewing tar in the early Holocene: an archaeological and ethnographic evaluation. Antiquity, 73, 579584.

Charters, S., Evershed, R. P., Goad, L. J., Heron, C., \& Blinkhorn, P. (1993). Identification of an adhesive used to repair a Roman jar. Archaeometry, 35, 91-101. doi:10.1111/j.1475-4754.1993.tb01025.x

Dominguez-Carmona, D. B., Escalante-Erosa, F., Garcia-Sosa, K., Ruiz-Pinell, G., Gutierrez-Yapu, D., Chan-Bacab, M. J., GimenezTurba, A., \& Pena-Rodriguez, L. M. (2010). Antiprotozoal activity of betulinic acid derivatives. Phytomedicine, 17, 379-382. doi:10.1016/j.phymed.2009.08.002

Drag, M., Surowiak, P., Drag-Zalesinska, M., Dietel, M., Lage, H., \& Oleksyszyn, J. (2009). Comparision of the cytotoxic effects of birch bark extract, betulin and betulinic acid towards human gastric carcinoma and pancreatic carcinoma drug-sensitive and drug-resistant cell lines. Molecules, 14, 1639-1651. doi:10.3390/molecules14041639

Dudd, S. N., \& Evershed, R. P. (1999). Unusual triterpenoid fatty acyl ester components of archaeological birch bark tars. Tetrahedron Letters, 40, 359-362. doi:10.1016/S0040-4039(98)02311-9

Eiznhamer, D. A., \& Xu, Z. Q. (2004). Betulinic acid: A promising anticancer candidate. IDrugs, 7, 359-373.

Fenech, M. (2007). Cytokinesis-block micronucleus cytome assay. Nature Protocols, 2, 1084-1104. doi:10.1038/nprot.2007.77

Fenech, M., Chang, W. P., Kirsch-Volders, M., Holland, N., Bonassi, S., Zeiger, E., \& Uman, H. (2003). HUMN project: Detailed description of the scoring criteria for the cytokinesis-block micronucleus assay using isolated human lymphocyte cultures. Mutation Research, 534, 65-75.

Grünberg, J. M. (2002). Middle Palaeolithic birch-bark pitch. Antiquity, $76,15-16$.

Hartmann, A., \& Speit, G. (1997). The contribution of cytotoxicity to DNA-effects in the single cell gel test (comet assay). Toxicology Letters, 90, 183-188. doi:10.1016/S0378-4274(96)03847-7

Hayek, E. W. H., Jordis, U., Moche, W., \& Sauter, F. (1989). A bicentennial of betulin. Phytochemistry, 28, 2229-2242. doi:10.1016/S0031-9422(00)97961-5

Henderson, L., Wolfreys, A., Fedyk, J., Bourner, C., \& Windebank, S. (1998). The ability of the Comet assay to discriminate between genotoxins and cytotoxins. Mutagenesis, 13, 89-94. doi:10.1093/mutage/13.1.89

Itkonen, T. I. (1984). Suomen lappalaiset vuoteen 1945. Porvoo: Söderström.

Koller, J., Baumer, U., \& Mania, D. (2001). High-tech in the middle Palaeolithic Neandertal-manufactured pitch identified. European Journal of Archaeology, 4, 385-397. doi:10.1177/146195710100400315

Krasutsky, P. A. (2006). Birch bark research and development. Natural Product Reports, 23, 919-942. doi:10.1039/b606816b

Krause, A. W., Carley, W. W., \& Webb, W. W. (1984). Fluorescent erythrosin B is preferable to trypan blue as a vital exclusion dye for mammalian cells in monolayer culture. Journal of Histochemistry \& Cytochemistry, 32, 1084-1090. doi:10.1177/32.10.6090533

Kumaravel, T. S., \& Jha, A. N. (2006). Reliable Comet assay measurements for detecting DNA damage induced by ionising radiation and chemicals. Mutation Research, 605, 7-16.

Modugno, F., Ribechini, E., \& Colombini, M. P. (2006). Chemical study of triterpenoid resinous materials in archaeological findings by means of direct exposure electron ionisation mass spectrometry and gas chromatography/mass spectrometry. Rapid Communications in Mass Spectrometry, 20, 1787-1800. doi:10.1002/rcm.2507

Muceniece, R., Saleniece, K., Rumaks, J., Krigere, L., Dzirkale, Z., Mezhapuke, R., Zharkova, O., \& Klusa, V. (2008). Betulin binds to 
gamma-aminobutyric acid receptors and exerts anticonvulsant action in mice. Pharmacology Biochemistry \& Behavior, 90, 712-716. doi:10.1016/j.pbb.2008.05.015

Perry, P., \& Wolff, S. (1974). New Giemsa method for the differential staining of sister chromatids. Nature, 251, 156-158. doi: $10.1038 / 251156 \mathrm{a} 0$

Pool-Zobel, B. L., Klein, R. G., Liegibel, U. M., Kuchenmeister, F., Weber, S., \& Schmezer, P. (1992). Systemic genotoxic effects of tobacco-related nitrosamines following oral and inhalational administration to Sprague-Dawley rats. Clinical Investigator, 70, 299-306. doi:10.1007/BF00184666

Regert, M. (2004). Investigating the history of prehistoric glues by gas chromatography-Mass spectrometry. Journal of Separation Science, 27, 244-254. doi:10.1002/jssc.200301608

Regert, M., \& Rolando, C. (1996). Archéologie des résidus organiques. De la chimie analytique à l'archéologie: Un état de la question. Techne, 3, 118-128.

Saleem, M., Murtaza, I., Witkowsky, O., Kohl, A. M., \& Maddodi, N. (2009). Lupeol triterpene, a novel diet-based microtubule targeting agent: Disrupts survivin/cFLIP activation in prostate cancer cells. Biochemical and Biophysical Research Communications, 388, 576582. doi:10.1016/j.bbrc.2009.08.060

Sauter, F., Jordis, U., Graf, A., Werther, W., \& Varmuza , K. (2000). Studies in organic archaeometry I: Identification of the prehistoric adhesive used by the "Tyrolean Iceman" to fix his weapons. Archive for Organic Checmistry, 1, 735-747.

Schlegel, R. A., \& Williamson, P. (2001). Phosphatidylserine, a death knell. Cell Death \& Differentiation, 8, 551-563.

doi:10.1038/sj.cdd.4400817

Sieroszewski, W., Stepanov, S. A., Zhornitskaia, M. I. A., \& Mukhamediarov, S. F. (1993). Iakuty: Opyt etnograficheskogo issledovaniia. Moskva: Assotsiatsiia "rossiiskaia polit entsiklopediia".

Stern, B., Clelland, S. J., Nordby, C. C., \& Urem-Kotsu, D. (2006). Bulk stable light isotopic rations in archaeological birch bark tars. Applied Geochemistry, 21, 1668-1673. doi:10.1016/j.apgeochem.2006.07.004

Tice, R. R., Agurell, E., Anderson, D., Burlinson, B., Hartmann, A., Kobayashi, H., Miyamae, Y., Rojas, E., Ryu, J. C., \& Sasaki, Y. F. (2000). Single cell gel/comet assay: Guidelines for in vitro and in vivo genetic toxicology testing. Environmental and Molecular Mutagenesis, 35, 206-221.

doi:10.1002/(SICI)1098-2280(2000)35:3<206::AID-EM8>3.0.CO;2$\underline{\mathrm{J}}$

Urem-Kotsou, D., Stern, B., Heron, C., \& Kotsakis, K. (2002). Birchbark tar at Neolithic Makriyalos, Greece. Antiquity, 76, 962-967.

Vermes, I., Haanen, C., Steffens-Nakken, H., \& Reutelingsperger, C. (1995). A novel assay for apoptosis. Flow cytometric detection of phosphatidylserine expression on early apoptotic cells using fluorescein labelled Annexin V. Journal of Immunological Methods, 184, 39-51. doi:10.1016/0022-1759(95)00072-I

Yogeeswari, P., \& Sriram, D. (2005). Betulinic acid and its derivatives: A review on their biological properties. Current Medicinal Chemistry, 12, 657-666. doi:10.2174/0929867053202214 